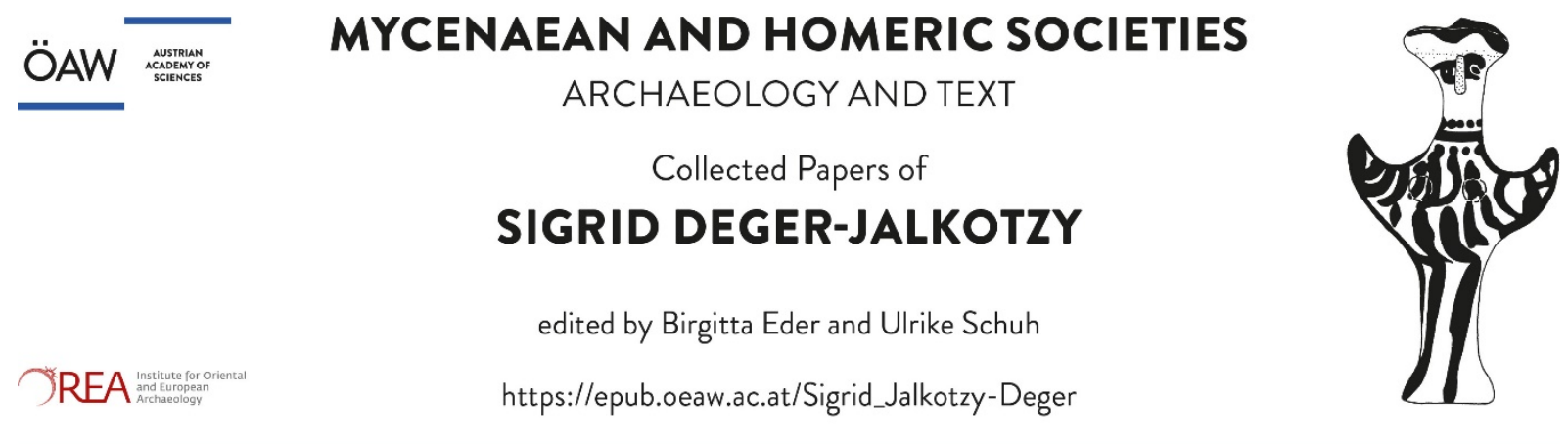

02.

S. Deger-Jalkotzy

\title{
The Women of PY An 607
}

Minos 13:2, 1972, 137-160

(C) Ediciones Universidad de Salamanca

mit freundlicher Genehmigung / with kind permission

Dieses Dokument darf ausschließlich für wissenschaftliche Zwecke genutzt werden (Lizenz CC BY-NC-ND), gewerbliche Nutzung wird urheberrechtlich verfolgt.

This document is for scientific use only (license CC BY-NC-ND), commercial use of copyrighted material will be prosecuted. 


\section{M
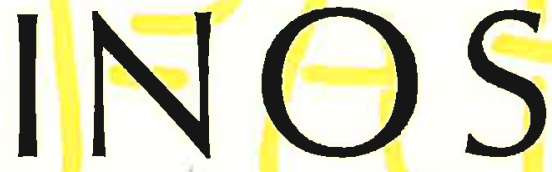

REVISTA DE FILOLOGIA EGEA

\section{Gomité de Redacción}

Francisco R. Adrados (Madrid) - Antonín BartonĚK (Brno) Emmett L. BennetT, jr. (Madison) · John Ghadwick (Cambridge) Alfred Heubeck (Nürnberg) · Michel Lejeune (Paris) • Olivier Masson (Paris) · Piero Meriggi (Pavia) - Emilio Peruzzi (Firenze) Giovanni Pugliese Garratelli (Roma) - Ernst Risch (Zürich) Gornelis J. RuIJGH (Amsterdam) - Antonio Tovar (Tübingen).

\section{Responsable:}

Martín S. RuipéRez (Madrid)

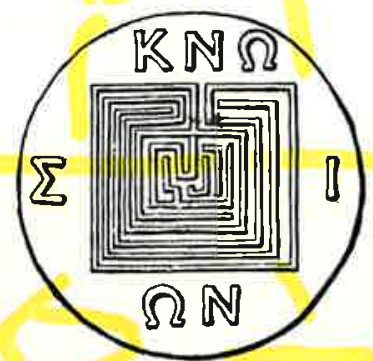

N. S. XIII, fasc. 2 (1972)

UNIVERSIDAD DE SALAMANGA

1973 


\section{N D I G E}

Págs.

Louis Godart - JeAN - PIERre Olivier: 98 raccords et quasi-raccords de fragments dans les tablettes de Cnossos . . . . . . . . . . . . . . . . . . . . . .

Ghristiane Sourvinou-Inwood: The Theban Stirrup-Jars and East Crete. Some Remarks. . . . . . . . . . . . . . . . . . . . . . . . . . 130

Sigrid Deger-Jalkotzy: The Women of PY An 607 . . . . . . . . . . . . 137

Gianfranco Maddoli: Le 40 da-ma-te di Pakijanija e le classi parallele Eo/En . . 161

Anna SAcconr: L'avorio nella tabella di Pilo Va 482 . . . . . . . . . . . . . . 173

Renato ARena: Greco ő $\mu \beta p$ ikos : ßó́kXos e miceneo o-mi-ri-jo-i . . . . . 182

MARtín S. Ruipérez - José VARA: Le mycénien et les traces d'occlusives finales dans le texte homérique. . . . . . . . . . . . . . . . . . . . . . . . 192

Piero Meriggr: I nuovi testi ciprominoici . . . . . . . . . . . . . . . . 197

\section{I S G E L A N E A}

The VIth International Congress of Classical Studies . . . . . . . . . . . . . . 259

José L. Melena: Further Comments on $* 142$ and $* 151$. . . . . . . . . . . . 259

J. T. Hooker: Sobre una nueva interpretación de e-ke-qe . . . . . . . . . . . . 260

\section{R E G E N S I O N E S}

Denis L. PAge: The Santorini Volcano and the Destruction of Minoan Crete(J.L. Melena) 262

Paul Wathelet: Les traits éoliens dans la langue de l'épopée grecque (J. L. García-

Ramón) . . . . . . . . . . . . . . . . . . . . . . 264

Publicaciones recibidas en la redacción. . . . . . . . . . . . 267 


\section{THE WOMEN OF PY An 607}

Time and again, this notoriously difficult text has attracted the interest of mycenologists ${ }^{1}$. There is no doubt that it could represent a most valuable source for our knowledge of Mycenaean society and probably of Mycenaean economy as well. But there are almost insurmountable difficulties which hinder a clear interpretation: out of the thirteen words which occur in this text, four are hapax legomena and two, although attested in other contexts, cannot be explained with certainty. Moreover, PY An 607 is an isolated text; there are no other tablets which it could be linked to or compared with, except for one thing: it was written by the same scribe as the set Aa 240-1182, together with An 292, Wa 114 and 1008. There are other peculiarities also in the arrangement of the statements given in this text which Bennett could not explain epigraphically ${ }^{2}$. They remain to be interpreted.

It is therefore not surprising that authors dealing with this subject have either based their interpretations on their etymolo-

1 PY An 607 has been treated by the following authors (in alphabetical order):

F. R. Adrados, «Do-qe-ja, diosa micénica de la fecundidad», Minos 5, 1957, pp. 53-57; E. L. Bennett, Jr., «Textual Notes. PY An 607», Minos 7, 1961, pp. 513; L. Deroy - M. Gérard, Le cadastre mycénien de Pylos, Roma 1965, pp. 120 ff.; C. Gallavotti, Documenti e struttura del greco nell'età micenea, Roma 1955-56, pp. 6870; Id., «Le origini micenee dell'istituto fraterico», $P d P$ 76, 1961, pp. 36 f.; M. Lejeune, «Textes mycéniens relatifs aux esclaves», Historia 8, 1959, pp. 131-133; Ya. L. Lentsman, Die Sklaverei im mykenischen und homerischen Griechenland, Wiesbaden 1966, pp. 185 ff.; S. Luria, «K voprosu o charaktere rabstva v mikenskom rabovladel'českom obščestve», Vestnik Drevnej Istorii 1957, pp. 8-24; L. R. Palmer, Gnomon 29, 1957, p. 566; Id., Mycenaeans and Minoans, London 1961, pp. 105 f.; Id., The Interpretation of Mycenaean Greek Texts, Oxford 1963, pp. 127 f.; D. Petruševska, «Kutereupi», ZA 15/1, 1965, p. 28; M. D. Petruševski, «Eqetai eeto teretewe», $\Varangle A 15 / 2,1966$, p. 352; G. Pugliese-Carratelli, «La decifrazione dei testi micenei», PdP 35, 1954, p. 95; F. J. Tritsch, "The Women of Pylos», Minoica. Festschrift 7. Sundwall, Berlin 1958, pp. 411 ff.; M. Ventris - J. Chadwick, Documents in Mycenaean Greek, Cambridge 1956, p. 167.

E. L. Bennett, Minos 7, 1961, pp. 5-13. 
gies of the difficult words mentioned above, sometimes running the risk of being carried away by their enthusiasm, or have refrained from giving any interpretation which goes beyond the facts which can be established with fair certainty, but are regrettably few. The present author also cannot claim to provide a solution, let alone a definite interpretation. But she hopes to be able to make some suggestions leading to a possible explanation by approaching the problem from a different angle.

It seems appropriate to start from the two facts which can be established with certainty: this tablet deals with women, and it presents their parentage. Apart from this, nothing is clear. We may safely assume that the number of the women was thirteen ${ }^{3}$. But regarding their parents, we are left with many problems. In the first place, the uniqueness of the text and the fact that there is no obvious link with any other tablet render it very difficult to discover for what purpose An 607 was written. Hence it is equally difficult to tell how rclevant the question of parentage is to the text. Was the palace administration mainly interested in a record of the women's parentage? Or was it the purpose of the text to register the women, and the parentage was a minor fact in connexion with the list? Certainly these are the principal problems which arise if one attempts to interpret An 607.' But before we are able to discuss them, we have to focus attention upon some questions which concern the parentage itself.

In all cases, at least one parent is referred to as a slave (|doelos/, |doela $/$ ), and this parent is always mentioned first. The statements concerning the mothers and fathers are in each case linked by the particle $-d e(\delta \dot{\varepsilon})$. The adversative function of this Greek particle has led to the conclusion that the statements about the girls' parents are opposed to each other. Consequently most authors agree that the women of PY An 607 have one parent who is a slave whereas the other one is a freeborn person.

Although one might argue for 26, it is difficult to disregard Bennett's epigraphical analysis of the text (op. cit.). He has shown convincingly that the numeral 13 in line 4 includes the 6 women of lines $2-3$ and the 7 women of lines 4-8. Thus, lines 3-4 represent a summarizing statement about all 13 women. It was meant to conclude the text, but as lines 5-8 were added later on, it happened to be in the middle; the scribe only erased the numeral and changed it to 13 . 
But it has to be pointed out that the interpretation of the statements concerning the parents depends upon the explanation of the word do-qe-ja. The authors mentioned above accept it as a nominative plural of a noun describing the women themselves. Yet there are others who doubt this interpretation and maintain that $d o-q e-j a$ has to be regarded as a divine name ${ }^{4}$. They base their opinion on the fact that $k i$-ri-te-wi-ja frequently occurs in religious contexts and appears to have, in these instances, a religious significance. On this view, the thirteen women appear as $k i$-ri-te-wi-ja of a goddess $d o-q e-j a$, and each of them has one parent who is called a «slave» of the same deity. Since these authors further agree that the term "slave of a deity» indicates a title rather than an actual slave status ${ }^{5}$, they hold that no one in this text is called a slave and dismiss the document altogether from the discussion of slavery. This interpretation seems, however, unconvincing. First, it is not proved that ki-ri-te-wi-ja is a religious term in all instances. There are cases where it is, at least, uncertain ${ }^{6}$. Moreover, this term is never connected with a divine name. It seems strange that a goddess $d o-q e-j a$ who is otherwise completely unknown should have $k i$-ri-te-wi-ja of her own whereas not even the ki-ri-te-wi-ja of pa-ki-ja-na (PY Eb 321/Ep 704) are connected by name with any of the female deities of the holy district. Further, the $k i$-ri-te-wi-ja of line 1 of our text are the same persons who are called do-qe-ja do-e-ra in line 3 ; there is no other instance of the term "slave of a deity» connected with the name $k i$-ri-te-wi-ja, nor does it ever coincide with any other title or occupational term. As a matter of fact, it is by no means certain that the expression «slave of a deity» was a mere title without regard to the actual status of the person concerned. It will be

4 This view is held particularly by F. R. Adrados, Minos 5, 1957, pp. 53-57; cf. also L. R. Palmer, Gnomon 29, 1957, p. 566; Id., Mycenaeans and Minoans, pp. 105 f.; Id., Interpretation, p. 128; E. L. Bennett, Jr., Minos 7, 1961, p. 10.

$5 \quad$ Gf. E. L. Bennett, Jr., «The Landholders of Pylos», AJA 60, 1956, pp. 103-133; Id., «Slavery», Nestor, vol. I, p. 73.

- Although KN E 777 is very obscure and PY Fn 1428 is very fragmentary, there is nothing which indicates conclusively a religious significance for these texts. Cf. M. Gérard-Rousseau Les mentions religieuses dans les tablettes mycéniennes, Roma 1968, p. 134. Cf. also below, p. 154. 
shown later on that it is very likely that the low-ranking temple personnel consisted of slaves who were provided by the palace ? The fact that the /theoio doeloi/ of the Pylos E series held small leases of land does not contradict this view. It is consistent with the type of slavery which can be presumed for Mycenaean society $^{8}$.

I therefore suggest we base the present discussion of the text on the interpretation of $d o-q e-j a$ as a description of the girls themselves whereas /doelos/ and /doelä/ refer to their respective father or mother. It then appears from line 3 that the $d o-q e-j a$ themselves were slave women, since they are called/doelai/. But the peculiar thing about them is that only one of their parents is characterized as a slave. We have already mentioned that some authors, on the basis of the statements given in lines 6 and 7 of our text (which are identical) and of the adversative function of the particle $\delta \dot{\varepsilon}$, have assumed that one parent was a slave and the other one was a free person. This view, however, is far from being proved. The fact that, in one instance, the mother lives at or originates from $k u$-te-re- $u-p i^{9}$ proves, by itself, nothing. There is no other reference to people from this place which could help to define the social status of the mother in line 2; and as we shall see later on, some indirect evidence suggests that this mother was an unfree rather than a free person. In the case of the di-wi-ja do-e-ra / Diwiās doela $/$ in line 5 it has been argued, again, that this term indicates a title rather than an actual slave status. But as we have already stated, there is nothing to support this assumption. Hence one has to admit that it does not follow from the text that the «non-slave» parents of the thirteen women actually were free.

\footnotetext{
Cf. below, pp. $152 \mathrm{f}$.
}

Cf. below, p. 147.

This place which recurs on PY Na 296 is an important producer of flax, recording the largest amount of flax among the various places of the Pylos $\mathrm{Na}$ series. According to Dr J. Chadwick, it is very doubtful whether this place can be identified as the island of Kythera. It is more likely that it was situated in the flax growing areas of the Pylian kingdom, and the high figure given in Na 296 points to the Further Province rather than to the Hither Province. Besides, a connexion of $k u$-te-re-u-pi with Kythera requires an interpretation of the word as an abl.-loc. of an ethnic /Kuthērēwes/; but there are no ethnics in -દús in Mycenaean Greek. 
But on the other hand, this cannot mean that both parents were ordinary slaves; in this case one would expect their children automatically to be considered as slaves. There would be no reason for mentioning the parents' respective social status altogether and linking these statements by the particle $\delta \dot{\varepsilon}$. In short, the information concerning the girls' parentage involves two problems: first, whatever difference there is between the social status of the father and the mother, it must imply slave status for their children; and secondly, we do not know if in Mycenaean society a marriage between a freeborn person and a slave had this consequence. This aspect of Mycenaean social life is not otherwise illuminated by the Linear B texts. But it certainly contains the clue to the question what was the purpose of this text.

Perhaps there is a possibility of approaching these questions from a different direction. It has been maintained that «in reconstructing the social history of an ancient people, deduction by analogy is legitimate, if the risk of oversimplification is not forgotten» 10 and, we would add, if the difficulty of defining adequate material for comparison is not underestimated. For these reasons, it seems necessary to discuss this method briefly before we proceed to apply it in the present instance. As for the comparative material, we have to refer to civilizations where slavery was part of the social structure and where, at the same time, an organization of social and/or economic life comparable to the Mycenaean type can be observed. In the first place, this is true for the peoples on the Ancient Near East, contemporary with or earlier than the Mycenaean civilization ${ }^{11}$. There is good reason to suppose that Mycenaean economy was structured, in principle, similarly to Mesopotamian and Syro-Palestinian patterns, although some variations, due to different requirements may be expected. The similarities can be explained both by the general similarities

\footnotetext{
R. A. Grossland, $M L S$ of March 8th 1967 (p. 337).

11 In the present case it is also legitimate to adduce the evidence from the Middle and Late Assyrian and Neo-Babylonian periods and from the Old Testament: these civilizations continued the practices of slavery of their predecessors in Mesopotamia and Palestine. Cf. I. Mendelsohn, Slavery in the Ancient Near East, New York 1949, esp. pp. $121 \mathrm{ff}$.
} 
among the civilizations of the Near East and the Aegean region during the Late Bronze Age and by the active trade relations among the peoples of the Eastern Mediterranean during the same period. The question whether they also suggest an analogous development of social organizations can be answered positively as far as the social structure responded to the economical facts, and slavery certainly was among these features ${ }^{12}$. In other cases, however, the different historical background of the Mycenaean civilization and its situation at the fringe of the Eastern Mediterranean world must be taken into account, and close examination will be required for each case.

There is also some material on slavery in Hittite society. Here, it has to be questioned to what extent we are entitled to draw parallels between the Hittite and Mycenaean social and economic organizations, if at all. Although one may think of some cultural exchange between these two peoples ${ }^{13}$, there is almost no evidence for direct trade relations, and all suggestions of direct political relations are based on material which is still disputed. Further, Hittite economy was based on self-sufficiency whereas the Mycenaeans mainly depended on their commerce.

On the other hand, Hittites and Mycenaeans had some things in common; first, they were both influenced by the urbanized peoples of the Near East. The Hittites, too, learned a great deal from them and imitated their achievements in social and economic organization whenever it met their own demand. Slavery as a means of obtaining cheap labour certainly was a case in point. Secondly, Mycenaeans and Hittites had a very similar background as regards historical development and structure of population; and they were both situated rather at the edge of the Near Eastern and Eastern Mediterranean civilizations. On the basis of these

Gf. Mendelsohn, Slavery, p. 121: «Slavery was a part of an economic pattern which remained constant through the ages...... the economic foundation - private ownership of land, intensive agriculture, small-scale shop industry and primitive techniques - remained and underwent almost no change at all. This situation produced a type of slavery that differed greatly from those in classical civilization and in America». tischen Zeit, Tübingen 1955, pp. 122 ff., pp. 298 ff., p. 422. Cf. also K. Bittel, Grundzüge der Vor- und Frühgeschichte Kleinasiens, Tübingen 1945, pp. 55 ff. 
similarities we may well use the Hittite evidence as comparative material for Mycenaean social structure generally, and for the present purpose in particular. It has to be explained, however, by parallel development rather than by direct contacts or mutual influence.

As regards slavery in classical Greek history, it has to be pointed out that economy and society were in that period based on entirely different principles. Thus, the Ancient Greek sources on slavery provide comparative material only in cases where aspects of slavery are due to its very nature and remain the same throughout the history of this social phenomenon.

The material which falls under these premises suggests that marriages between freeborn persons and slaves were common in the Ancient Near East and in Anatolia. But there was a great variety of patterns among the different societies. In Ancient Babylonia it is only the marriage between a free woman and a slave which was recognized legally, and the Code of Hammurabi refers explicitly to a slave of the palace or a slave of a muškenûm ${ }^{14}$ as a lawful husband for a «lady» ( $\S \S 175-176)$. Since these slaves apparently were of superior order to the ordinary slave of a free man ${ }^{15}$, nothing can be deduced from these paragraphs as to the legal effect, if any, of a marriage between a free woman and an ordinary slave. Nor is there any reference to a freeborn man as husband of a slave woman. $\S \S 146-147$ and 170-171 of the Code discuss only a concubinage between a master and his own or

The term muškenûm indicates a person who pledged his services to the state in return for certain economic grants, such as fief-holding and protection by the crown. Though not a slave, the $m$. was in some sense dependent on the palace and ranked socially between a slave and a free man. The institution was of great antiquity, going back to the period before 3000 B.c.; it was known outside Babylonia, to the Assyrians the Canaanites, the people from Mari, Ugarit and Alalakh. The semantic force of the term signifying a person who was subject to the king and functioned under restrictions gave the word a derived sense of «pitiable, underprivileged»; as such it survived in the sense of «poor, indigent» in Arabic and hence was taken into Italian («meschino») and French («mesquin»). Cf. E. Speiser, «The muškenûm», Orientalia, n.s. 27, 1958, pp. 19-28; G. R. Driver - J. C. Miles, The Babylonian Laws I, Oxford 1952 (abbrev.: Driver-Miles, BL), pp. 91-95. 
his wife's slave girl ${ }^{16}$. Occasionally, a slave girl could be described as her master's (inferior) "wife» who, however, was not allowed to put herself forward as an equal of the legal wife. If she offended the legal wife, she was to be treated like an ordinary slave ${ }^{17}$.

The Assyrian Laws contemplate a marriage between a free man and his so-called esirtu ${ }^{18}$. This term originally meant «prisoner of war» or "captive maid» and was applied, later on, to a concubine; captive women presumably could be sold into slavery if they did not become their masters' concubines ${ }^{19}$. On the other hand, the master could marry his concubine legally. She then had to be veiled in public which was the privilege of a free woman ${ }^{20}$. The same happened if a hierodule became the lawful wife of a free man ${ }^{21}$. Otherwise, slave girls and hierodules were not allowed to be veiled and were in this respect treated along with prostitutes. They faced severe punishment if they offended this law ${ }^{22}$. This leads to the conclusion that in Assyria an unfree woman (slave or hierodule) who became the lawful wife of a free man (the master in the slave woman's case) was assimilated in status to a free woman. There are no references to a free woman marrying a slave.

In an Accadian text from Ugarit, a master frees his female slave and, at the same time, marries her to somebody else ${ }^{23}$. Otherwise, slave girls are mentioned only as their masters' concubines, and there is no evidence of free people marrying slaves. But the material is so scanty that it is not possible to conclude that marriages of this kind did not exist in Ugarit at all ${ }^{24}$.

16 Driver-Miles, $B L$ I, p. 305.

$17 \S \S 146-147$ of the Hammurabi Law Code. Cf. Driver-Miles, BL I, pp. $304 \mathrm{f}$.

G. R. Driver - J. C. Miles, The Assyrian Laws, Oxford 1935, (abbrev.: DriverMiles, $A L), \S 41$.

10 Driver-Miles, $A L$, p. 128.

so $\S 41$ (Driver-Miles, $A L$ ).

2140 .

$28 \S 40$.

3 On the Ugaritic evidence cf. A. van Selms, Marriage and Family Life in Ugaritic Literature, Pretoria 1954. A similar case is attested in the Old Testament, I Chron. 2: 34-5.

s4 G. van Selms, op. cit., p. 19. 
Marriages between free persons and slaves apparently were quite frequent with the Hittites. Several paragraphs of the Hittite Law Gode deal with marriages between a siave and a free woman as well as with those between a free man and a slave woman ${ }^{25}$. There are regulations for special cases which suggest that a mixed marriage of the kind described could have an effect on the legal status of the woman. $\S$ I 31 of the Code discusses the marriage between an unfree woman and a free man, together with the conditions in case of a divorce and the subsequent distribution of the children. In this instance, the wife is referred to by the term which is usually applied to a free woman ${ }^{26}$. From this it has been concluded ${ }^{27}$ that a slave woman obtained the status of a free person when she married a free man. However, it is not clear if this also applied when an unfree father-in-law paid the bride-price on behalf of a free but impecunious young man, thus securing him as a legally recognized husband for his daughter ${ }^{28}$. Two interesting but not entirely intelligible paragraphs ${ }^{29}$ state that a freeborn woman who was «taken» by a shepherd or an ABRIG ${ }^{30}$ without paying the bride-price, should become unfree after a certain period. Apparently, this union was not considered a legal marriage, and it has been suggested that the men concerned were slaves ${ }^{31}$. Indeed, it would otherwise be difficult to explain why the woman was deprived of her free status. In all, it seems as though in Hittite society intermarriage of slaves and free persons was a common feature, and that it was even necessary to make regulations for doubtful cases.

From all this evidence, together with the Nuzian testimonies for marriages of this kind ${ }^{32}$, one can deduce that unions between slaves and free people were familiar to the civilizations of the

\footnotetext{
15

J. Friedrich, Die hethitischen Gesetze, Leiden 1959, I, §§ 31-36; II, § 60.

26 The Hittite terminology otherwise is very precise. The paragraphs in question always refer to «unfree» or «free» persons explicitly.

7. V. Koroseč, «Einige Beiträge zum hethitischen Sklavenrecht», Festschrift Paul Koschaker III, Weimar 1939, pp. 127-139.

28 I $\S 36$ (Friedrich).

ง I $\S 35$; II $\S 60$ (Friedrich); cf. also below, p. 147 and n. 40.

so For this very obscure term cf. A. Goetze, Kleinasien, München 1957, p. 107.

31 V. Koroseč, loc. cit.

32 Cf. Mendelsohn, Slavery, p. 13, pp. 56 f.
} 
Near Eastern and Eastern Mediterranean world during the second millenium B.C. It is therefore legitimate to assume this practice for the Mycenaeans, as well. As to the details, however, it is idle to speculate. The comparative material shows a great range of variety, and it is impossible to tell which patterns the Pylians may have adopted. PY An 607 could, theoretically, refer to marriages of this kind.

But there is still the other question which needs to be answered: is it likely that these marriages implied a slave status of the offspring? As far as this question is concerned, the information given by the comparative material is remarkably uniform: generally, the children born of a legal marriage between a slave and a freeborn person were free ${ }^{33}$.

In Babylonia also the children born of concubinage between a slave girl and her master were to be set free after the owner's death; if he had adopted them during his life-time, they were heirs to his property ${ }^{34}$. The latter was also true for Assyria ${ }^{35}$ whereas the practice in Ugarit was different: children born by a slave woman to her master were slaves ${ }^{36}$; they had high value if the father was a nobleman. On the other hand, there is evidence for the manumission of a slave before marriage to a free person ${ }^{37}$. Thus, the children of this marriage were free, and the general pattern also was true for Ugarit.

The exceptions to the rule are the following: in Babylonia, children born of a marriage between a free person and a templeslave were not free; even the third generation of a temple-slave who had married a free woman was claimed by the temple as its property ${ }^{38}$. Similarly, some Late Assyrian documents testify that children of hierodules were dedicated as servants to temples, but it is not clear whether this corresponded to an automatic procedure or not. - The Hittite Law Code decrees that children

\footnotetext{
Hammurabi Law Code, $\S \S 175-176$ (Driver-Miles, $B L$ II); Hittite laws, I $\S 31$ -

32 (Friedrich); Assyrian Laws, § 41 (Driver-Miles, $A L$ ).

34 Hammurabi Law Code, $\S \S 170-171$ (Driver-Miles, $B L$ II).

35 § 41.11-13 (Driver-Miles, $A L$ ): cf. Driver-Miles, $B L$ I, p. 351.

3 Gf. van Selms, op. cit., pp. 75 f., p. 97.

$\because \quad$ Cit. above, p. 144.

s8 Cf. Mendelsohn, Slavery, p. 104.
} 
born of a union between a shepherd or a so-called ABRIG and a free woman ${ }^{39}$ should be «slandered». As these passages are obscure, it is difficult to provide an adequate interpretation. In any event, this union does not appear to be a legally recognized marriage ${ }^{40}$. The statement concerning the children indicates that they were held in low esteem, as their mother lost her free status; but it is not laid down expressly that these children actually became slaves.

Returning now to PY An 607, one meets great difficulties in maintaining that this tablet refers to marriages between free persons and slaves. It would imply that in Mycenaean society children born of such a connubium generally became slaves, a feature unknown to all comparable civilizations of the time. Theoretically, this could have been the case, since there is no proof against this assumption. But keeping to the method which has been adopted for the present analysis, I am more inclined to doubt this view. Why should the Mycenaeans be the only people to depart from a pattern which was consistent among all contemporaneous systems and practices of slavery? The evidence which we possess for slavery in Pylos and Knossos suggests that the Mycenaean type cannot have been very different from its Near Eastern and Eastern Mediterranean counterparts ${ }^{41}$. Particularly interesting in this connexion is the slave's right of obtaining land-ownership and property consisting in livestock which is attested for the Mycenaean civilization by the Linear B texts. In the Near East and with the Hittites, this peculium of slaves played an important part in the legal texts which discuss a union between a slave and a free person ${ }^{42}$. In Babylonia, Assyria and Palestine a slave could enjoy his peculium only during his lifetime; legally it belonged to his master to whom it descended

\footnotetext{
s9 $\quad$ Cf. above, p. 145.

40 The texts (I $\S 35$, II $\S 60$ ) refer to the fact that the men in question did not pay the bride-price (which apparently was the condition of the legally recognized marriage). Nor do they say that the woman was «taken» as a wife; $\$ 60$ even speaks of an "abduction».

1 For a recent discussion of this question cf. Lentsman, Die Sklaverei im mykenischen und homerischen Griechenland, Wiesbaden 1966.

4 Cf. above, ns. 33-35.
} 
after the slave's death ${ }^{43}$. But when the peculium was accumulated jointly by a slave and his freeborn wife, the slave's owner could claim only the slave's share, and the wife kept her share for herself and the children. Consequently, the children's right of inheriting this property of the free parent had to be ensured, i.e. they were legally regarded as free persons ${ }^{44}$. The Hittites likewise took the slave's right of accumulating a peculium for granted. This follows from the passages of the Law Code which concern the dissolutiou of marriages among slaves and marriages between slaves and free people ${ }^{45}$. Again one may expect that in the case of a mixed marriage, at least, the children had a claim to the inheritance of the free parent's property, which implied that they had to be regarded as free persons. The type of slavery we are dealing with recognized that the slave, though legally a chattel, was a human being with certain inalienable rights. The Mycenaean slave evidently was granted at least one of these rights, the accumulation of property. It is also from this point of view that it seems unlikely that a mixed marriage gave rise to slave status for the children.

Against this, it is no use quoting the instance of the Gortynian Law ${ }^{46}$ which lays down that a free woman's children by a $\delta$ õ $\lambda$ os husband were unfree, if she moved to the unfree husband's house.

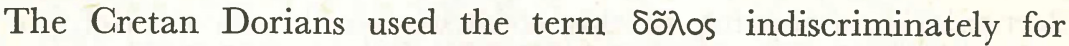
domestic slaves and for serfs (who were bound to the soil, but otherwise treated as free persons) ${ }^{47}$, and their economical and social organization was entirely different from the urbanized and palatial civilizations of the second millenium B.c.

Thinking in terms of a concubinage between a free person and a slave rather than of a legal marriage is ruled out by the fact that in two instances it is the father who was the slave; a free woman as a slave's concubine is incompatible with social systems

4. Cf. Mendelsohn, Slavery, pp. 66 ff.

44 Cf. also Driver-Miles, $B L$ I pp. $355 \mathrm{f}$.

45 Hittite Laws, I $\S \S 31-32$ (Friedrich).

46 Gortynian Law, § VII.1 ff. (C. D. Buck, The Greek Dialects, Chicago-London $1965^{3}, \mathrm{Nr}$ 117). This argument was used by Lentsman in his interpretation of PY An 607 (op. cit., p. 187).

47 Cf. G. Busolt, Griechische Staatskunde I, München 1920, p. 135; p. 285 and n. 4). 
of the kind we are concerned with. The Hittite Law Code shows what happened to a free woman if she was kept in an illegal alliance by an apparently unfree man ${ }^{48}$. But even for her children it is not decreed explicitly that they became slaves ${ }^{49}$.

Yet there is another important point. The thirteen women of An 607 are treated collectively which indicates that they belonged to one and the same owner; but in contrast to the general practice of the Pylian scribes, an individual owner's name is missing ${ }^{50}$. In this respect they are linked to the women listed in the Aa, $\mathrm{Ab}$ and Ad series of Pylos, and this connexion is supported by the fact that the same scribe was responsible for An 607 and Aa 240-1182, together with An 292. The women mentioned in these texts doubtless belonged to the personnel working for the palace. Most probably they were slaves, similar to the state slaves who are quoted and listed in numerous Near Eastern documents. Consequently it can be assumed that the women of An 607 also were slaves who belonged to and were disposed of by the palace. This ownership is perhaps indicated by the word ke-ri-mi-ja in line 1. It occurs only once elsewhere, on the Knossos tablet Lc 535. As Killen and Olivier have shown ${ }^{51}, \mathrm{KN}$ Lc 536 totals the quantities of cloth given on individual tablets of the same class which are not characterized by a «collector's» name. This could imply that Lc 535 is the total for tablets with a «collector's» name. Maybe both in PY An 607 and KN Lc $535 k e-r i-m i-j a$ refers to the palace directly, but not so much as the centre of production and administration than as the place where these slaves actually lived and worked. In this sense, ke-ri-mi-ja could well indicate something like the Babylonian bìt asīin, a camp

48 G. above, pp. 145 and 147.

40 The argument that only the daughters became slaves and the families were split up is contrary to the comparative evidence and seems, in itself, rather improbable. Gf. Driver-Miles, $B L$ I, pp. 338-341.

so On the general practice of indicating the owners of slaves cf. M. Lejeune, Historia 8, 1959, pp. $138 \mathrm{ff}$.

"1 J.-P. Olivier, «La série Dn de Cnossos», SMEA 2, 1967, pp. 71-93; J.-P. OlivierJ. T. Killen, «155 raccords de fragments dans les tablettes de Cnossos», $B C H$ 92, 1968, p. 137. 
where the king's slaves were housed ${ }^{52}$, or the Hittite «Houses of the Seal», the royal storehouses, where the slaves of the king worked ${ }^{53}$.

If the women of An 607 were palace slaves, it is logical to assume that those parents who are described as |doelos/ and $\mid$ doela $\mid$ also were slaves in the service of the palace. This makes it even more difficult to think, in their case, of marriages between free people and slaves, since a palace slave generally was of superior order to the slave of an ordinary free man ${ }^{54}$.

Turning to the principal argument which has been put forward in favour of the theory that An 607 refers to marriages between slaves and free people, it has to be pointed out that it is not proved that the /khalkêres/ mentioned in lines 6 and 7 were free people. Both the comparative material and the Linear B texts show that slave bronzesmiths were a well-known phenomenon among the civilizations of the Late Bronze Age in the Near East, in Anatolia and in the Aegean. The social status of craftsmen varied greatly, from a free and independent status $\mathbf{5 5}$ through several ranks of free but dependent people working in the service of the palaces ${ }^{56}$, down to the status of skilled slaves who worked in the palace or were owned by private persons ${ }^{57}$. Slave bronzesmiths are also known from the Pylos Jn series; it cannot be excluded that they belonged, in a sense, to the palace,

52 Originally, the bit asiri $i$ was a war captive camp but counted among its inmates large numbers of the king's slaves with their families who were descendants of war prisoners (cf. Mendelsohn, Slavery, p. 1). It is particularly interesting that among the women of the Pylos Aa series there are some who are called ra-wija-ja / |lāwiaiai/, «captives».

53 Cf. A. Goetze, Kleinasien, p. 109.

s4 Cf. above, p. 143.

s5 Gf. H. Schmökel, «Mesopotamien», Kulturgeschichte des Alten Orient, Stuttgart 1961, p. 42; I. Mendelsohn, "Gilds in Babylonia and Assyria», JAOS 60, 1940, pp. 68-72; Hittite Laws, I $\S \S 40-41$ (Friedrich).

so On the muškenûm cf. above, n. 14.

67 In the Old Babylonian period the number of skilled slaves was not considerable, whereas in the Neo-Babylonian period handicrafts were mostly in the hands of slaves, cf. Drives-Miles, BL I, pp. 394 f.; Mendelsohn, Slavery, pp. 112 ff., with references to Late Assyria and Palestine. Cf. also Hittite Laws, II $\S 61 \mathrm{~b}$ (Friedrich) and KUB XIII 8 Ov $13 \mathrm{ff}$. 
since their masters certainly worked in its service ${ }^{58}$. Therefore, there is no reason to assume a priori that the bronzesmiths mentioned in An 607 were free men.

As a result, I suggest we leave aside a widely accepted assumption and consider the possibility that both parents of the women of PY An 607 were, in fact, unfree. The tablet refers rather to different categories of slaves who were owned by the palace and supervised and registered by the palace officials (it can be assumed that in Pylos, as in the Near East and in Hatti, no clear line could be drawn between the property of the king and that of the state). It was a well known practice throughout the history of slavery to increase the number of slaves by mating male and female slaves. Marriages among various kinds of palace slaves in Pylos probably were the outcome of the same policy. This would explain the accuracy in describing the girls' parentage, comparable to the detailed Ancient Near Eastern records of several classes of palace slaves.

It can therefore be suggested that the text in question lists several categories of slaves who were at the disposal of the palace of Pylos. The terms $\mid$ doelos $/$ and $\mid$ doela $\mid$ refer to people who represented the bulk of the slave labour utilized by the palace, and their provenance probably reflected the various sources of slavery in the Ancient World. Some groups of palace slaves, however, were registered apart from these $\mid$ doeloi $/$ : the slaves working at places outside the Pylian palace itself, the «temple» slaves and the skilled slaves.

We know from the Pylos $\mathrm{Aa}, \mathrm{Ab}$ and Ad series that not all palace slaves were kept at Pylos; a large number worked at various other places of the kingdom. There are reasons to assume that some palace slaves lived at $k u$-te-re- $u$-pi, although the series mentioned above do not record this place-name: particularly the Ad tablets refer several times to flax-workers (ri-ne-ja /lineiai/) who were kept at places which recur among the flax-producing

s8 Gf. Ventris-Chadwick, Documents, p. 352, with parallels from Ur and Alalakh; the slaves probably were sent to these smiths in order to learn the trade (on this kind of apprenticeship cf. also Hittite Laws, II § 86b, and Mendelsohn, Slavery, pp. $113 \mathrm{f}$.). Perhaps the smiths of the Pylos Jn series represented a class similar to the muškenûm of the Near East (cf. above, n. 14)? 
areas listed in the $\mathrm{Na}$ series ${ }^{59}$. Along with these places, the $\mathrm{Na}$ series records $k u$-te-re- $u$ - $p i$ as the largest producer of flax ${ }^{60}$. It would be indeed suprising, if the palace did not use its slave labour at this very place, and it appears likely that the woman mentioned in line 2 of our text was a /lineia/. The laconic statement ma-te-de ku-te-re-u-pi in itself probably implied that she was employed in flax working: the information which we have about $k u$-te-re-u-pi suggests that the importance of that place consisted solely in flax growing, and any slave who lived there was likely to be used for the cultivation and processing of flax. Thus, the scribe of An 607 was able to save space. The fact that $k u$-te-re-u-pi does not occur in the $\mathrm{Aa}, \mathrm{Ab}$ and Ad series could be explained by the incompleteness of these series; presumably the information concerning this place had not yet come in. From the passage under study it appears further that the girls, although they must have been still young ${ }^{61}$, were considered old enough to be separated from their mother. Presumably they had been transferred to the palace and introduced into their future trade. The mother remained at $k u$-te-re- $u$-pi. As we have seen, the place-name must have sufficiently indicated her "particulars»; the Aa, Ab and Ad series show that the palace kept a strict record of its slaves, and the palace officials certainly recognized to which group of slaves this particular woman belonged. The individual was, in any case, of no relevance.

The di-wi-ja do-e-ra of line 5 most probably was a slave of the sanctuary of the goddess $\mid$ Diwi $\bar{a} \mid$. The archaeological evidence shows that Mycenaean temples did not possess the wealth and economic power which were significant for the temples of the Near Eastern and particularly the Mesopotamian type. As a matter of fact, there are only a few examples of self-contained temple units within Mycenaean communities ${ }^{62}$. In most cases Mycenaean deities were worshipped in shrines situated within the palace area or at places which were regarded as holy. As

po-to-ro-wa-pi: Na 262 Ad 678; re-u-ko-to-ro: Na 419 Ad 326; ke-e: Na 577 $(k e-i-j o) \sim \mathrm{Aa} 93$.

Bo Cf. above, n. 9.

61 Cf. also below, p. 156.

62 Cf. the evidence from Keos, Mycenae, Eleusis. 
for Pylos, the Linear B texts attest a holy district in close connexion with the palace, $p a-k i-j a-n a$, where the deities of the kingdom had their sanctuaries. The large number of texts concerned with personnel and various commodities for religious ceremonies suggest that the Pylian king himself was responsible for matters of cult and religion, resembling in this respect the Hittite king. Among other things, the palace presumably provided the labour for the various sanctuaries of the Pylian deities. Texts like PY Ae 303 support this view, and it cannot be a mere accident that |Direiā| is mentioned among the gods of PY Tn 316. In the same way as An 607, a list of female palace personnel from Mari records hierodules next to ordinary palace slaves like cooks or women of the harem ${ }^{63}$.

As regards the bronzesmiths of lines 6 and 7, it has been shown earlier ${ }^{64}$ that they were, in all probability, slaves. The reason why they were listed separately may be sought in the fact that skilled slaves at all times were highly valuable; probably the Pylian slave bronzesmiths belonged to special workshops, attached perhaps to the free bronzesmiths who worked in the service of the palace.

In regard to the parentage of the women of An 607, we now may sum up: in contrast to the generally accepted idea, we have arrived at the conclusion that these women were not born of marriages between free people and slaves. This follows both from deduction by analogy on the basis of the comparative material which has been defined and selected under the conditions laid down by way of introduction, and from the internal evidence of the Linear B texts. In all probability, these parents were slaves of the palace, i.e. of the king of Pylos; the particle $\delta$ ' indicated different groups or ranks of slaves rather than a different social status.

Consequently the women of An 607 were already born as palace slaves and as such presumably trained, from the beginning, for a certain kind of work; hence it appears advisable to accept the word do-qe-ja as an occupational noun, designating 
a special kind of worker. The character of this occupation is qualified by the adjective ki-ri-te-wi-ja which may, despite other opi-

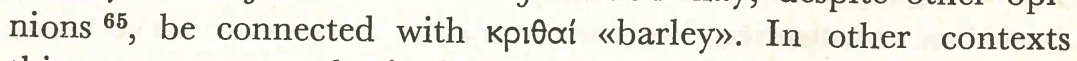
this term apparently indicates a female religious occupation. Yet this does not necessarily prove that An 607 is a text concerned with religious affairs ${ }^{66}$. Barley certainly played a part in religious ceremonies, as we know also from classical Greek practices, but that does not imply a religious significance for all mentions of this grain or of people handling it. In the first place, barley was used for food. Therefore, it is more likely that the do-qe-ja of An 607 were women whose work had especially to do with barley. Some authors have connected do-qe-ja with $\delta \rho \varepsilon \dot{T} \omega \omega$ and interpreted the term as (barley) «reaper» ${ }^{67}$. Others prefer to connect it with Sóptrov ${ }^{68}$; do-qe-ja then would mean «women who are occupied with the meal», i.e. «cooks». This interpretation cannot be ruled out altogether, in view of a Hittite record which quotes the deportation of female NAM.RA people some of whom

E.g. Deroy-Gérard, Le cadastre mycénien de Pylos, pp. 132 ff. (cf. contra, A. Heubeck, Gnomon 42, 1970, p. 813); also M. Gérard-Rousseau, Mentions, pp. 79 ff.

68 Cf. above, p. 139 and n. 6.

67 Ventris-Chadwick, Documents, p. 167.

68 C. J. Ruijgh, Etudes sur la grammaire et le vocabulaire du grec mycénien, Amsterdam 1967, p. 251 and n. 88; cf. also G. Pugliese-Carratelli, PdP 35, 1954, p. 95. It is true that in Homer the word Sóprov is used for the evening meal. On the other hand, it is not proved that «evening meal» is the original significance of the word. In Homer it is also the main meal of the day which was taken after the day's work and which took more preparations and was more elaborate than the other meals. Theoretically, Sóptrov could designate the main meal of the day in the first place, and the usage in Homer follows from the fact that in the Mediterranean this meal is taken in the evening. The English word «dinner» e.g. is used both for the midday and for the evening meal; the usage varies as to region and social class, and, as I have been told, depends basically on the time when the main meal is taken. A Dutch instance is extremely interesting. As Mr. F. Waanders has informed me, the word «middageten» («midday meal») is nowadays often used for the evening meal; this reflects the shifting of the main meal from midday to the evening, caused by the changes of the way of life. Although the term is contradictory in itself to an evening meal, it has been preserved. However, it

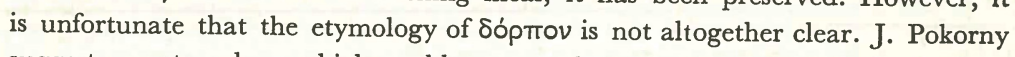
suggests an etymology which could support the view mentioned above (Indogermanisches Etymologisches Wörterbuch I, p. 210). 
were «porridge-cooks» ${ }^{69}$. There is further a passage from the Iliad which describes the preparation for a feast: men slaughtered and roasted an ox and women sprinkled the roast flesh with meal

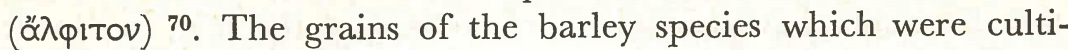
vated at that period were tightly enclosed by their husks and could be separated from them only by application of heat ${ }^{71}$. This was done shortly before cooking. In this sense «barley cook» would indicate a rather complex occupation which included the roasting, threshing and grinding of the barley. However, is is impossible to decide on this question. We have to be content with defining do-qe-ja ki-ri-te-wi-ja as an occupational term which indicates women whose work consisted, in some way, in the handling of barley.

Another problem in connexion with the women of PY An 607 concerns their families. We have already suggested that they were daughters of unions between palace slaves of various categories. Now the question arises whether these unions can be thought of in terms of permanence, i.e. of marriage, and whether the girls grouped together in each entry can be regarded as sisters. Here, the comparative material does not help since the ancient civilizations took divergent lines in this respect; some recognized marriages and family relations among slaves, others did not ${ }^{\mathbf{7 2}}$. However, a positive answer to the question is suggested by the fact that lines 6 and 7 give identical statements about the girls'

KUB XXVI 69 V 14; On the NAm.RA people see S. Alp, «Die soziale Klasse der NAM.RA-Leute und ihre hethitische Bezeichnung», Jahrbuch für kleinasiatische Forschung 1, 1950/51, pp. 113-135; A. Goetze, Kleinasien, p. 106 and n. 2. Il. XVIII, 558-560.

71 E. G. Curwen, Plough and Pasture, London 1946, pp. 101-106; G. W. Dimbleby Plants and Archaeology, London 1967, p. 83.

The Assyrians seem to have respected family ties among slaves, cf. J. KohlerA. Ungnad, Assyrische Rechtsurkunden, Leipzig 1913; various documents attest that entire slave families were bought (e.g. $\mathrm{Nr} 60$ ). However, there are also cases of women sold with their babies, cf. op. cit., $\mathrm{Nr} 208,192,66$. The Hittites recognized marriages between slaves and even provided for the children in case such a marriage was dissolved, cf. Hittite Laws, I § 33 (Friedrich). In Babylonia, family ties were generally disregarded in the disposal of slaves; wives were sold without their husbands and vice versa, and even young children were separated from their parents. It was only occasionally that a slave and his wife were sold together. Cf. Mendelsohn, Slavery, pp. $40 \mathrm{f}$. 
parents ${ }^{73}$; if the scribe in lines 7 and 8 did not refer to sisters but to do-qe-ja who had the fact in common that their mother was a $\mid$ doela $/$ and their father a bronzesmith, one would expect that he would have changed the numeral of the first statement rather than added another identical entry. Hence one is inclined to think of two couples with one and three daughters respectively, and a union which gave rise to at least three children (boys are not counted) can doubtless be called a permanent one. It is also possible that line 2 refers to a family with six daughters. But this question is bound up with some epigraphical difficulties. The text, originally, consisted of lines 1-4 only, and line 4 was meant to conclude the text as a summarizing statement ${ }^{74}$. But when these four lines were half-dry, lines 5-8 were added, presumably because more information came in. It seems as though the scribe still expected further data, since the tablet is ruled through to the bottom. Thus one gets the impression that lines 1-4 were composed carefully, whereas the following entries were added, one after the other, as the scribe received the information. Probably he intended to copy the text out again but was prevented from doing so; An 607 does not have the appearance of a final redaction. On these grounds and on basis of the considerations mentioned above, we may assume that the three groups of do-qe-ja listed in lines 5-8 represented, in each case, sisters. But it remains uncertain whether this is true for the $d o-q e-j a$ of line 2 as well. We have to take into account the fact that the girls must have been still very young because they were identified by their parentage; one would not expect this in the case of women of a more advanced age. Of course, one could think of a family with six daughters who succeeded one another at short intervals. But it is equally possible that the scribe, when he copied out the text of the first four lines, comprehended in line 2 girls who were not sisters but were all characterized by the fact that their fathers were |doeloi/ and their mothers were at ku-te-re-u-pi. However, this problem cannot be solved definitely as long as we have to suspect that the tablet represents two different stages of redaction.

13 This point has been observed particularly by F. J. Tritsch, Minoica. Festschrift 7. Sundwall, pp. 413 f. and n. 14.

7. G. above, n. 3. 
Finally, we have to return to the question which we have characterized as the main problem of PY An 607: what purpose was this tablet written for? There are other texts which refer to palace slaves at me-ta-pa, and some of these texts were written by the same scribe as An 607; yet none parallels it. To my opinion, the clue to this problem lies in the statement given in lines 3 and 4: the thirteen women had been consigned to the $\mid H_{e} q^{u}$ etail at me-ta-pa. It seems plausible to assume that the central administration kept a detailed record of palace slaves who were sent elsewhere and placed under the supervision or at the disposal of somebody else. Unfortunately, we do not know for what purpose the girls were sent to the /Hequetai/; were they destined to work on the royal domains at me-ta-pa under the supervision of the /Hequetai/, the king's representatives? Or were they presented by the king to the /Hequetail as their personal property? The text of the two lines mentioned above could be interpreted in both ways: «13 do-qe-ja, (palace) slaves, have been sent to the |Hequetail .......», or: «13 do-qe-ja have been sent as slaves to/for the $\mid$ Hequetai $\mid$.......».

Perhaps it would be easier to find the answer if we knew what the word te-re-te-we means. Several interpretations have been offered, but both a place-name ${ }^{75}$ and a nominative plural ${ }^{76}$ or dative singular ${ }^{77}$ in -eús seem rather unlikely. It appears more plausible to think of a final dative of a noun of action in $\mid$-tus $\left.\right|^{78}$ which indicates the purpose of the consignment of the girls to me-ta-pa. However, the word remains obscure. But the uniqueness of the text has to be taken into consideration. It the supervision of palace slaves who worked on the royal domains

is Cf. L. R. Palmer, Gnomon 29, 1957, p. 566; Id., Interpretation, p. 475; E. L. Bennett, Jr., Minos 7, 1961, p. 12; M. D. Petruševski, ¿ $A$ 15, 1966, p. 352. The text clearly refers to me-ta-pa; besides, we can trace two /Hequetai/ at me-ta-pa, whereas it is difficult to see why there should be two or more /Hequetai/ at a "place» te-rete-we which is otherwise completely unknown.

70 On the difficulties in connexion with this interpretation cf. Bennett, loc. cit.

7 C. S. Luria, Vestnik Drevnej Istorii 1957, p. 175; F. R. Adrados, Minos 5, 1957, pp. 53-57.

is Gf. G. J. Ruijgh, op. cit., p. 93. Although in classical Greek the dative was no longer used in this sense, it seems certain that Mycenaean Greek still preserved this aspect of the dative: cf. /trisi dzeugeusi/ in PY Ub 1318. 
belonged to the duties of a /Hequetās/ one would expect that other texts, too, refer to this fact. Yet although there are many palace slaves who worked at places outside the Pylian palace, some even at me-ta-pa itself, there is no indication at all that the /Hequetai/ had to do with them. Hence one is inclined to believe that these slave women were sent to me-ta-pa especially for the /Hequetai/. One could imagine that they were handed over to them as their property. There are instances from the Ancient Near East and from the Hittite Empire in which the king distributed slaves as gifts among his followers and high officials ${ }^{79}$. I hope to be able to suggest on another occasion that the /Hequetai/, too, sometimes obtained their slaves and their landed property from the king. Since there are no other mentions of $d o-q e-j a$ in the Linear B texts, one could perhaps think of domestic workers who were taken for granted in any household but were not yet at the disposition of the /Hequetai/; this could apply to «barley cooks» as well as to «barley reapers». If the do-qe-ja were sent to the /Hequetail as a gift, one might explain the tablet as a document recording the donation and giving a list and description of the girls who were handed over to the /Hequetai/. Yet it is also possible that the girls were sent to the /Hequetai/ by the palace in order to work on their estates, but remained in the possession of the king; or the /Hequetai/ were supposed to control these slaves locally on behalf of the king.

In this case one might see in An 607 a record serving to identify these slaves later on. In any case, I think that the main purpose of the text was to preserve a list and description of thirteen slave women who were $d o-q e-j a$ by occupation and who were sent to $m e-t a-p a$ and placed at the disposal of the /Hequetai/. The parentage served as a means of describing or identifying them. It has the merit that it indicates the family background of the girls, and, at the same time, the parents' status among the palace slaves. Further, it tallies with the kind of information given by the scribes of the $\mathrm{Aa}, \mathrm{Ab}$ and Ad series about the palace slaves; it records the name of the place where the women lived, their occupation and their number. It only adds some more details. Even the 
parentage finds, to some extent, a parallel in those texts which register the children of the various women ${ }^{80}$.

Thus, the Pylian officials certainly recognized by the text of An 607 which categories of slaves both the do-qe-ja and their parents belonged to. As in the series mentioned above, the slaves were treated collectively, and names play no part. The scribe who was responsible for An 607, An 292 and Aa 240-1182 apparently was more concerned with figures than with individuals. Thus, the description given in PY An 607 may have been thought sufficient to identify the do-qe-ja.

We do not know how many /Hequetai/ there were at me-ta-pa. From the evidence of the Pylos tablets we can trace two. Aq 218.4 mentions ro-u-ko ku-sa-me-ni-jo, known as |Hequetās| from An 519.15f., and locates him at me-ta-pa. Another /Hequetās/, a-re-kutu-ru-wo e-te-wo-ke-re-we-i-jo, is attached to the me-ta-pi-jo ke-ki-de of An 654.3ff. Although the tablet does not locate the $0-k a$ of $k u-r u-m e-n o$, there are reasons to assume that $a-r e-k u$-tu-ru-wo came, in fact, from $m e-t a-p a$ : there is the name of the $k e-k i$-de whom he accompanies, and $e-r u$-ta-ra, an "officer» of the same $o-k a$, is mentioned in Aq 64.16 as at me-ta-pa. It is possible that there were still other /Hequetai/ at me-ta-pa; the form e-qe-ta-i invites one to think in these terms, although the Linear B spelling of the dual dative of masculine $a$-stems is still unknown. In any case, thirteen slaves could be distributed among two people as well as among several persons; but one would not envisage a high number of |Hequetai/.

As I have already said by way of introduction, it is not possible to give a conclusive interpretation of PY An 607, as long as almost half its words remain unintelligible. Nevertheless, I believe that we have gained some points which may lead to a satisfactory explanation of the text. By applying the comparative method we were able to examine the problem of the parentage from a new angle, and it now appears unlikely that the hypothesis of mixed marriages between slaves and free people can be maintained. There is good reason to assume that the parents of the concerned but also mentions their fathers (PY Ad 684). 
thirteen $d o-q e-j a$ were all slaves. From this point we started further investigations. We arrived at the conclusion that these girls and their parents were palace slaves. This links An 607 to the Aa, $\mathrm{Ab}$ and Ad series and to other texts related to them, a link which is confirmed by the fact that many of these texts were written by the same hand as our tablet. Yet at the same time it sets An 607 apart from those texts as it does not represent a routine register of slave women owned by the palace. It refers to the transfer of some palace slaves into the custody or even into the possession of certain /Hequetail at me-ta-pa. Such a transfer certainly was extraordinary, and the uniqueness of the text suggests that it was the only one at the time when the tablets were written ${ }^{81}$. The unusual wording of the text may be due to the fact that the palace wanted to keep a record of the transfer and a sufficiently detailed description of the women concerned by which they could be identified. Thus, PY An 607 may be accepted as complementary information to the texts mentioned above; and what is more, it illustrates the social position of a $\mid H_{e} q^{u} e t \bar{a} s /$ and it gives an insight into the policy of the Pylian palace towards its personnel ${ }^{82}$.

Schulgasse 43 a / 22

1180 Wien

Sigrid Deger-Jalkotzy

81 F. J. Tritsch has raised the same point although he thinks of a different kind of transfer, cf. Minoica, p. 413.

82 I am deeply indebted to Dr J. Chadwick who kindly revised the English text of this paper; I am also grateful for his encouragement and stimulating criticism which greatly helped me throughout its preparation. 